\title{
Two new species of Rhabdochona (Nematoda: Rhabdochonidae) from freshwater fishes in Thailand
}

\author{
František Moravec ${ }^{1}$ and Thanapon Yooyen ${ }^{2}$ \\ ${ }^{1}$ Institute of Parasitology, Biology Centre of the Academy of Sciences of the Czech Republic, Branišovská 31, 37005 České \\ Budějovice, Czech Republic; \\ ${ }^{2}$ Department of Biology, Faculty of Science, Chiang Mai University, Thailand
}

\begin{abstract}
Two new species of rhabdochonid nematodes are described from the intestine of freshwater fishes in Chiang Mai Province, northern Thailand: Rhabdochona (Rhabdochona) pseudomysti sp. n. from the catfish Pseudomystus siamensis (Regan) (Bagridae, Siluriformes) in the Fang Brook, a tributary of the Kok River (the Mekong River basin), Fang District and Rhabdochona (Globochona) thaiensis sp. $\mathrm{n}$. from the cyprinid Mystacoleucus marginatus (Valenciennes) (Cyprinidae, Cypriniformes) in the Ping River (the Chao Phraya River basin), Muang District. Rhabdochona pseudomysti is mainly characterized by simple, leaf-like oval deirids (a unique feature among Rhabdochona spp.), a prostom with 14 anterior teeth, the presence of basal prostomal teeth, the length ratio of the muscular and glandular portions of oesophagus (1:2.1-2.6), an unusually long left spicule (1.10-1.22 mm), length ratio of spicules (1:11.5-14.7), arrangement of genital papillae, and conspicuously elevated vulval lips. Rhabdochona thaiensis differs from other representatives of the subgenus Globochona Moravec, 1972 possessing caudal projections on the tail tip in that it has only 2 claw-shaped projections located ventrally on the tail tip of both males and females; the species is mainly characterized by the presence of distinct pseudolabia, 8 anterior prostomal teeth, absence of basal teeth, bifurcated deirids, length ratio of the muscular and glandular portions of oesophagus (1:11.3-11.9), conspicuously short (135-141 $\mu \mathrm{m})$ left spicule, arrangement of genital papillae, and somewhat elevated vulval lips. Fully developed eggs of $R$. pseudomysti and $R$. thaiensis remain unknown. These are the first nominal species of Rhabdochona reported from Thailand.
\end{abstract}

Keywords: parasitic nematode, Rhabdochona, freshwater fish, Mystacoleucus, Pseudomystus, Thailand

The freshwater fish nematodes in Thailand remain little known. Pearse (1933) was the first to describe two species of camallanids, Camallanus ophiocephali $[=\mathrm{Ne}$ ocamallanus ophiocephali (Pearse, 1933)] from Channa striata (Bloch) (later the same species was reported from "Thai goby" in Thailand by Moravec and Scholz 1991), and Thelazo glossogobii [= Procamallanus glossogobii (Pearse, 1933)] from Glossogobius giuris (Hamilton). Subsequent records of nematodes from Thai freshwater fishes were rather scarce (e.g., Sirikanchana 1982, Kumchoo 2000, Purivirojkul 2009) and not identified to species. In her unpublished thesis, only Kumchoo (2000) reported four unidentified species of Rhabdochona Railliet, 1916 (designated as Rhabdochona sp. and Rhabdochona sp. I-III), collected from nine species of fishes in the Maesa Stream, Doi Suthep-Pui National Park, Chiang Mai Province.

During recent investigations of some freshwater fishes in Fang and Muang Districts, northern Thailand, nematodes referable to Rhabdochona were recovered from the intestine of Mystacoleucus marginatus (Valenciennes)
(Cyprinidae, Cypriniformes) and Pseudomystus siamensis (Regan) (Bagridae, Siluriformes). A detailed study of these nematodes using the light and scanning electron microscopy has shown that they represent two new species with very different morphology. Their descriptions are presented herein.

Mystacoleucus marginatus (maximum size $20 \mathrm{~cm}$ ) and Pseudomystus siamensis (maximum size $15 \mathrm{~cm}$ ) are tropical freshwater fishes, both native in Thailand. The distribution of the former species includes the Mekong, Chao Phraya and Meklong basins, and also the Malay Peninsula, Borneo, Sumatra and Java, whereas the latter species occurs in the Meklong River and Peninsular and Southeast Thailand river systems (Froese and Pauly 2010).

\section{MATERIALS AND METHODS}

Specimens of Pseudomystus siamensis $(\mathrm{n}=3)$ were collected by fishing nets in the Fang Brook, a tributary of the Kok River (the Mekong River basin), Fang District, Chiang Mai Province in April 2010, whereas those of Mystacoleucus marginatus $(\mathrm{n}=8)$ were caught by a local fisherman in the Ping River (the 
Chao Phraya River basin), Muang District, Chiang Mai Province in March 2010. The nematodes recovered were washed in physiological saline and then fixed in cold $4 \%$ formaldehyde solution. For light microscopy (LM) examination, the nematodes were cleared with glycerine. Drawings were made with the aid of a Zeiss drawing attachment. Specimens used for scanning electron microscopy (SEM) were postfixed in $1 \%$ osmium tetroxide (in phosphate buffer), dehydrated through a graded acetone series, critical-point-dried and sputter-coated with gold; they were examined using a JEOL JSM-7401F scanning electron microscope at an accelerating voltage of $4 \mathrm{kV} \mathrm{GB}$ low. All measurements are in micrometres unless otherwise indicated. The names of fishes follow FishBase (Froese and Pauly 2010).

\section{RESULTS}

Family Rhabdochonidae Travassos, Artigas et Pereira, 1928

\section{Rhabdochona (Rhabdochona) pseudomysti sp. n.} Figs. 1, 2

Description: Medium-sized nematodes with transversely striated cuticle (Fig. 2 D). Oral aperture hexagonal to oval, provided with four distinct submedian plates (sublabia), and surrounded by four small submedian cephalic papillae and pair of lateral amphids (Figs. $1 \mathrm{C}$, 2 A,B). Prostom funnel-shaped, with distinct small basal prostomal teeth (Fig. 1 D,E). Anterior margin of prostom armed internally with 14 small, forwardly directed teeth ( 3 dorsal, 3 ventral and 4 on each side); one tooth may be exceptionally doubled or absent (Figs. 1 C, 2 A,B). Vestibule rather long (Fig. 1 A,B,D,E). Deirids small, simple (non-bifurcated), leaf-like, oval, situated near middle of vestibule or somewhat anterior to it (Figs. 1 D-F, 2 C,D). Glandular oesophagus markedly short and narrow, only approximately twice as long as muscular oesophagus (Fig. 1 A). Tail of both sexes conical, with somewhat rounded tip (Fig. $1 \mathrm{I}, \mathrm{J}$ ).

Male (5 specimens; measurements of holotype in parentheses): Length of body 10.68-12.76 (11.91) mm, maximum width 95-122 (109). Prostom 18-21 (21) long and 15-18 (18) wide in lateral view. Length of vestibule including prostom 129-159 (135). Muscular oesophagus 186-249 (186) long, maximum width 21-24 (24); glandular oesophagus 450-600 (450) long, maximum width 24-30 (30); length ratio of both parts 1:2.3-2.6 (1:2.4). Length of vestibule with prostom and entire oesophagus forms $6-9(6) \%$ of body length. Nerve ring, excretory pore and deirids 198-210 (198), 303-345 (303) and 60-87 (66), respectively, from anterior extremity. Preanal papillae: 6-7 (7) pairs of subventral papillae, lateral papillae absent. All 6 postanal pairs of papillae subventral (Fig. 1 G). Longitudinal ventral cuticular ridges (area rugosa) absent. Left spicule conspicuously long, measuring 1.10-1.22 (1.22) mm; its shaft 303-399 (303) long, representing 25-34 (25)\% of entire spicule length; distal tip of spicule slightly expanded, blunt, with cuticular membrane (Fig. 1 G,L). Right spicule 81-99 (90) long, without dorsal barb at distal tip (Fig. $1 \mathrm{~K}$ ). Length ratio of spicules 1:11.5-14.7 (1:13.6). Tail 270-297 (297) long.

Female (3 specimens with immature eggs; measurements of allotype in parentheses): Length of body 15.22 21.75 (21.75) mm, maximum width 150-163 (163). Prostom 24 (24) long and 21 (21) wide in lateral view. Length of vestibule including prostom 135-150 (150). Muscular oesophagus 276-303 (303) long, maximum width 24-27 (27); glandular oesophagus 585-705 (705), maximum width 24-39 (39); length ratio of both parts 1:2.1-2.3 (1:2.3). Nerve ring, excretory pore and deirids at 201-207 (207), 354-375 (375) and 60-84 (84), respectively, from anterior extremity. Vulva postequatorial, 8.09-11.02 (11.02) $\mathrm{mm}$ from anterior extremity, at 51-56 (51)\% of body length. Vulval lips elevated, 6-57 (57) high (Fig. $1 \mathrm{H})$. Vagina directed posteriorly from vulva. Only immature eggs present in uterus. Tail 225-255 (255) long (Fig. $1 \mathrm{M}$ ).

Type host: Pseudomystus siamensis (Bagridae, Siluriformes).

Site of infection: Intestine.

Type locality: Fang Brook, a tributary of the Kok River (Mekong River basin), Fang District, Chiang Mai Province, northern Thailand (collected April 2010).

Prevalence and intensity: In all 3 P. siamensis examined; 14-28 (mean 21) specimens per fish.

Deposition of type specimens: Institute of Parasitology, Biology Centre of the Academy of Sciences, České Budějovice (Cat. No. N-958).

E t y m o log y: The specific name of nematode is derived from the generic name of the fish host (in genitive).

Remarks. According to Moravec (2010), the nematode genus Rhabdochona includes 92 species considered as possibly valid. However, an additional two species, $R$. $g u$ bernaculus Kakar, Bilqees, Kamran et Mukhtar, 2010 and R. ictaluri Aguilar-Aguilar, Rosas-Valdez et Pérez-Ponce de León, 2010, have been described since (Kakar et al. 2010, Aguilar-Aguilar et al. 2010). Whereas the latter species appears to be well established, the former, because of its poor and somewhat confused description, should be considered a species inquirenda. In addition, Moravec et al. (2010) have recently designated six nominal species of Rhabdochona as new junior synonyms and considered R. edentati Paul et Majumdar, 1994 to be a species incertae sedis.

Of all so far known species of Rhabdochona, R. pseudomysti is easily differentiated by a few morphological and biometrical features. The presence of simple, leaf-like oval deirids is unique within Rhabdochonidae; most species of Rhabdochona possess bifurcate deirids and only some of them, e.g., R. acuminata (Molin, 1860), R. anguillae Spaul, 1927 or R. fabianae Ramallo, 2005, have simple, rod-like or strongly reduced deirids (Saraiva and 


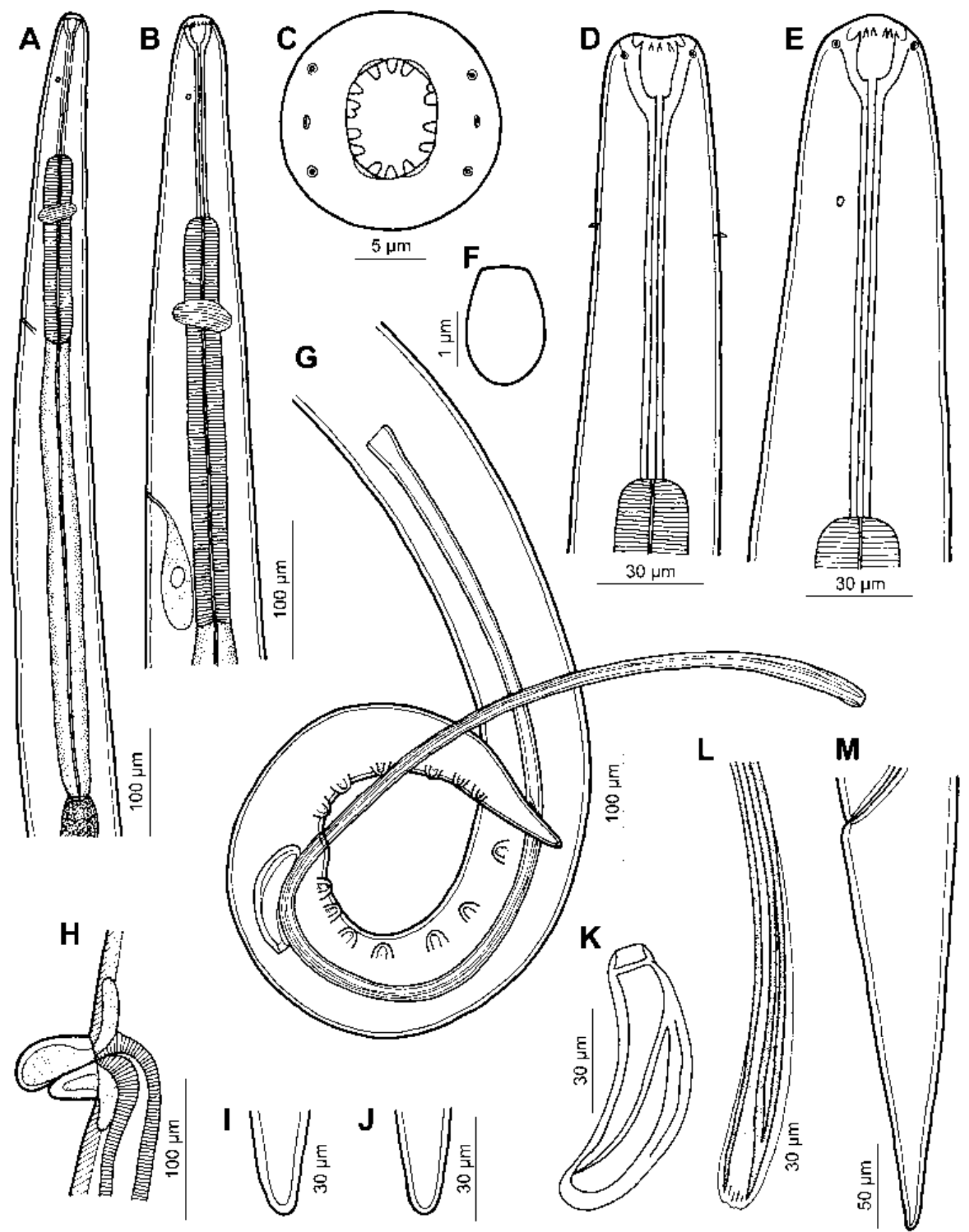

Fig. 1. Rhabdochona pseudomysti sp. n. A - anterior part of body, lateral view; B - anterior end of male, lateral view; $\mathbf{C}$ - cephalic end, apical view; D, E - anterior (vestibular) part of female body, dorsoventral and lateral views, respectively; $\mathbf{F}$ - shape of deirid; $\mathbf{G}$ - posterior end of male, lateral view; $\mathbf{H}$ - vulva, lateral view; $\mathbf{I}, \mathbf{J}$ - tail tip of male and female, respectively; $\mathbf{K}$ - right spicule; $\mathbf{L}$ - distal end of left spicule; $\mathbf{M}$ - tail of female, lateral view.

Moravec 1998, Cremonte et al. 2002, Caspeta-Mandujano et al. 2005, Ramallo 2005, Moravec 2010); only one species, R. papuanensis Moravec, Ríha et Kuchta, 2008, is known to possess hammer-shaped deirids (Moravec et al. 2008). However, the study of the exact shape of deirids in Rhabdochona usually requires SEM examination, but this method has not yet been used for the majority of species. Conspicuously elevated vulval lips in $R$. pseudomysti are another unique feature within Rhabdochona.
A remarkable character of the new species is its unusually long left spicule measuring 1.1-1.2 mm. Only in the following seven species of Rhabdochona this spicule attains or exceeds the length of $1 \mathrm{~mm}$ : R. kidderi Pearse, 1936 and $R$. decaturensis Gustafson, 1949 from catfishes and some other fishes in North America (Mexico, USA), $R$. srivastavai Chabaud, 1970 and $R$. puylaerti Moravec, 1983 from gobiid fish and a viper, respectively, in Africa (Madagascar, Uganda), and R. longicauda Djalilov, 

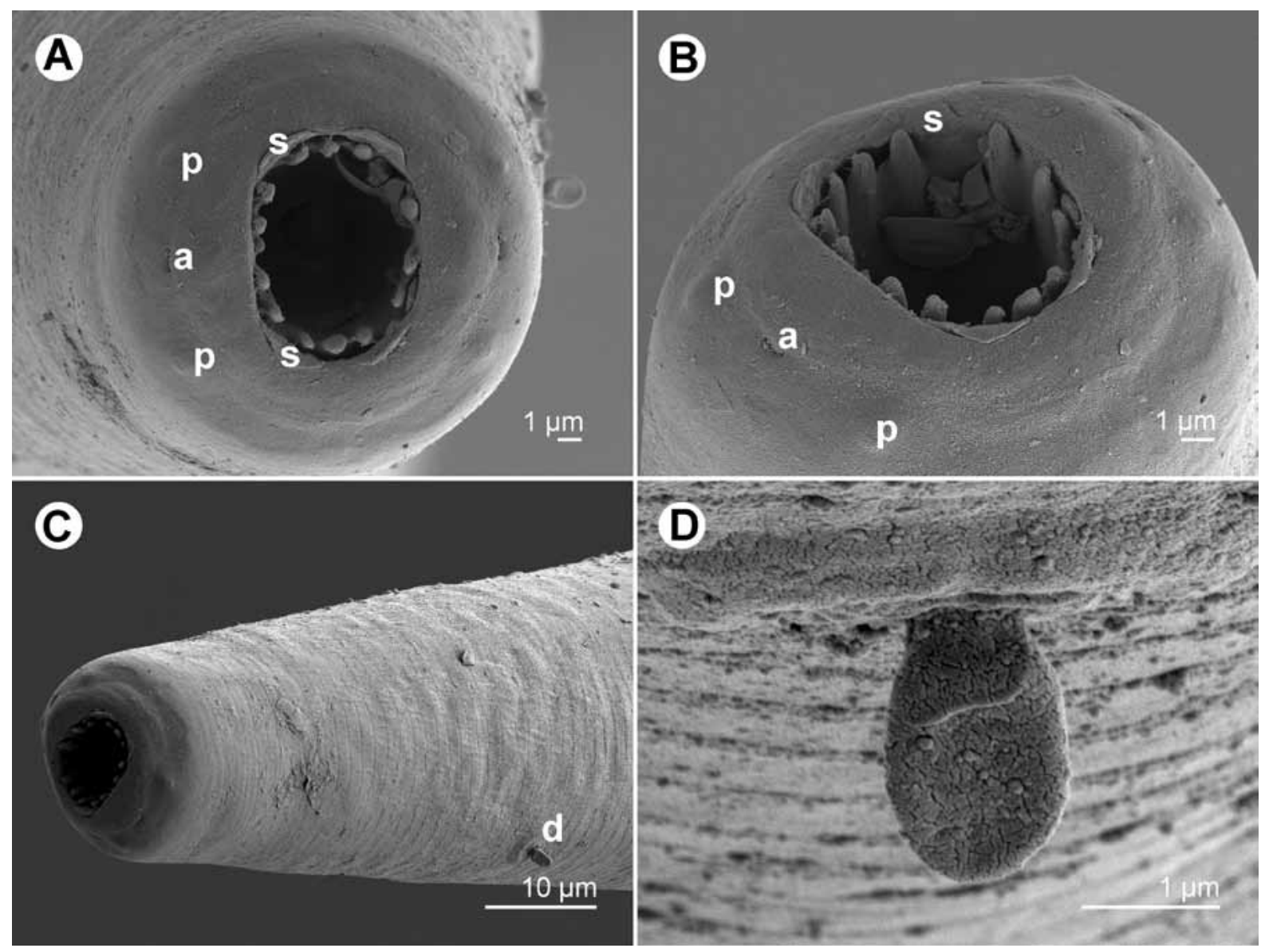

Fig. 2. Rhabdochona pseudomysti sp. n., scanning electron micrographs. A, B - cephalic end, apical and ventrolateral views, respectively; C-anterior end of body, sublateral view; D-deirid. Abbreviations: a - amphid; d-deirid; $\mathrm{p}$ - cephalic papilla; $\mathrm{s}$ - sublabium.

1964, R. garuai Agrawal, 1965 and R. prosthopori Wang, 1986 from fishes in Asia (Tadjikistan, Afghanistan, India, China) (Moravec and Arai 1971, Moravec 1972a, b, 1975, 1983, Moravec and Amin 1978, Wang 1986). Of them, R. garuai, reported from catfishes belonging to Bagridae and Schilbeidae in India, differs from $R$. pseudomysti mainly in having only 8 (vs. 14) prostomal teeth and was assigned by Moravec (1975) to the subgenus Globochona Moravec, 1972. All remaining species, except for R. prosthopori, possess 14 anterior prostomal teeth and belong to the nominotypical subgenus Rhabdochona; prostomal teeth in $R$. prosthopori, a parasite of the cyprinid Plagiognathops microlepis (Bleeker) in China, are reported to be 10 in number (Wang 1986), but they were not studied in apical view and, therefore, this number is not reliable.

In contrast to $R$. pseudomysti, the deirids of $R$. longicauda, R. kidderi, R. puylaerti and $R$. srivastavai are bifurcate (Moravec 1972b, 1983, Moravec et al. 1995), whereas those of $R$. decaturensis are simple, strongly reduced (Moravec and Arai 1971); the shape of deirids in $R$. prosthopori is unknown. Both the above-mentioned Asian species also differ from $R$. pseudomysti in some other features: $R$. longicauda, a specific parasite of the catfish Glyptosternon reticulatum McClelland (Sisoridae) in Tadjikistan and Afghanistan, in the characteristic structure of the tail tip and the number and arrangement of genital papillae (Djalilov 1964, Moravec 1975, Moravec and Amin 1978), whereas $R$. prosthopori in the shape (markedly narrower) of the right spicule and very different numbers of preanal and postanal papillae (Wang 1983).

A unique feature of $R$. pseudomysti within Rhabdocho$n a$ spp. seems to be the conspicuously short and narrow glandular oesophagus, only approximately twice as long as the muscular oesophagus. In other species of Rhabdochona, the glandular oesophagus is much longer than the muscular oesophagus and usually occupies the whole body width (see, e.g., the following species $R$. thaiensis). The markedly narrow and relatively short glandular oesophagus was previously described for Rhabdochona (R.) hakyi Moravec et Sey, 1988, a parasite mainly of catfishes in Vietnam (Moravec and Sey 1988), but its length relative to that of the muscular oesophagus is distinctly greater than in $R$. pseudomysti. 
The general morphology of $R$. pseudomysti indicates that this species belongs to the subgenus Rhabdochona, as defined by Moravec (1975). Species of this subgenus belong to three morphological groups based on surface structures on fully developed eggs: A - species with smooth eggs or eggs provided with a fine irregular gelatinous coating; $\mathrm{B}$ - species with filamented eggs; $\mathrm{C}-$ species with eggs provided with special polar swellings. Only immature eggs of $R$. pseudomysti are known, so that it is impossible to assign this species to any of the above mentioned morphological groups. Since both related Asian species ( $R$. longicauda and $R$. prosthopori) have filamented eggs, it may well be that filaments are also present on the fully developed eggs of $R$. pseudomysti.

\section{Rhabdochona (Globochona) thaiensis sp. n.}

Figs. 3, 4

Description: Medium-sized nematodes with transversely striated cuticle (Fig. 4 A,C,F). Oral aperture oval, provided with four rather large submedian plates (sublabia), and surrounded by four small submedian cephalic papillae and pair of lateral amphids; lateral lobe-like, somewhat elevated pseudolabia distinctly developed, each with small transverse groove at its top (Figs. $3 \mathrm{D}$, 4 A,B). Prostom funnel-shaped, without basal teeth (Fig. $3 \mathrm{C}$ ). Anterior margin of prostom armed internally with 8 fairly large, forwardly directed teeth (2 dorsal, 2 ventral and 2 on each side) (Figs. 3 D, 4 A,B). Vestibule of medium length (Fig. 3 A-C). Deirids small, bifurcate, situated at anterior half of vestibule (Figs. 3 C,E, 4 C,D). Glandular oesophagus 11-times longer than muscular oesophagus, occupying entire width of body (Fig. 3 A). Tail of both sexes conical with rounded tip bearing two minute claw-shaped ventral projections (Figs. 3 G,H,J,K, 4 F,G).

Male (holotype; measurements of 1 paratype in parentheses): Length of body 9.38 (8.84) mm, maximum width 109 (122). Prostom 24 (24) long and 15 (15) wide in lateral view. Length of vestibule including prostom 165 (165). Muscular oesophagus 321 (324) long, maximum width 21 (21); glandular oesophagus 3.62 (3.69) $\mathrm{mm}$ long, maximum width 99 (90); length ratio of both parts $1: 11.3$ (1:11.4). Length of vestibule with prostom and entire oesophagus forms 44 (47)\% of body length. Nerve ring encircling muscular oesophagus 201 (198) from anterior extremity; excretory pore at 273 (321). Preanal papillae: 9 (9) subventral and 2 (2) lateral pairs; latter situated slightly anterior to third pair and between fourth and fifth pairs of subventrals (counting from cloacal opening). Postanal papillae: 6 (6) pairs, of which 4 (4) pairs subventral and 2 (2) lateral; lateral pairs approximately at level of first and third pairs of subventrals (Figs. 3 F,G, 4 E). Longitudinal ventral cuticular ridges (area rugosa) well developed. Left spicule markedly short, 141 (135) long; its shaft 87 (60) long, representing $62(44) \%$ of entire spi- cule length; distal tip of extruded spicule slightly widened, blunt (Fig. 3 F,G,M,N). Right spicule boat-shaped, 60 (60) long, without dorsal barb at distal tip (Fig. 3 F,G,L). Length ratio of spicules 1:2.35 (1:2.25). Tail 177 (207) long, with rounded tip bearing two minute ventral clawshaped projections 3 (3) long.

Female (allotype): Length of body $14.58 \mathrm{~mm}$, maximum width 177 . Prostom 27 long and 18 wide in lateral view. Length of vestibule including prostom 177 . Muscular oesophagus 393 long, maximum width 21; glandular oesophagus $4.66 \mathrm{~mm}$, maximum width 87 ; length ratio of both parts $1: 11.9$. Nerve ring, excretory pore and deirids at 219, 402 and 81, respectively, from anterior extremity. Vulva postequatorial, $9.18 \mathrm{~mm}$ from anterior extremity (at $63 \%$ of body length); vulval lips somewhat elevated (Fig. 3 I). Vagina directed posteriorly from vulva. Only small number of immature eggs present in uterus. Tail 216 long, with rounded tip bearing two minute clawshaped ventral projections 3 long (Fig. $3 \mathrm{H}$ ).

Type host: Mystacoleucus marginatus (Cyprinidae, Cypriniformes).

Site of infection: Intestine.

Type locality: Ping River (Chao Phraya River basin), Muang District, Chiang Mai Province, northern Thailand (collected March 2010).

Prevalence and intensity: In 3 of $8 M$. marginatus examined; 1 specimen.

Deposition of type specimens: Institute of Parasitology, Biology Centre of the Academy of Sciences, České Budějovice (Cat. No. N-959).

Etymology: The specific name of nematode relates to the country of its origin, i.e., Thailand.

Remarks. Based on the number (8) of anterior prostomal teeth, absence of lateral alae and the presence of caudal projections on the tip of the tail, these nematodes can be assigned to the subgenus Globochona Moravec, 1972, as rediagnosed by Moravec (1975). To date, only a few species of Rhabdochona (Globochona) are known from freshwater fishes in tropical and subtropical Asia and Africa (Moravec 1975, Boomker and Petter 1993, Wang et al. 1994).

Of them, only the following 9 species are characterized by possessing caudal projections on the tail tip, either only in female or in both sexes: $R$. barusi Majumdar et De, 1971 from Barilius sp. in India, R. brevichona Wang, Yu et Wu, 1994 from Rectoris luxiensis Wu et Yao in China, R. chodukini Osmanov, 1957 from Barbus spp. in Central Asia (Aral Sea basin), R. congolensis Campana-Rouget, 1961 reported from many fish species in Africa, R. equispiculata Moravec et Scholz, 1991 from Hampala spp. in Laos, R. gambiana Gendre, 1922 from an unidentified fish, Barbus eutaenia Boulanger and Raimas moorii (Boulanger) in Africa (Gambia and the Democratic Republic of Congo), R. onychostomi Wang, Yu et Wu, 1994 from Onychostoma simum (Sauvage et Dabry de Thiersant) 


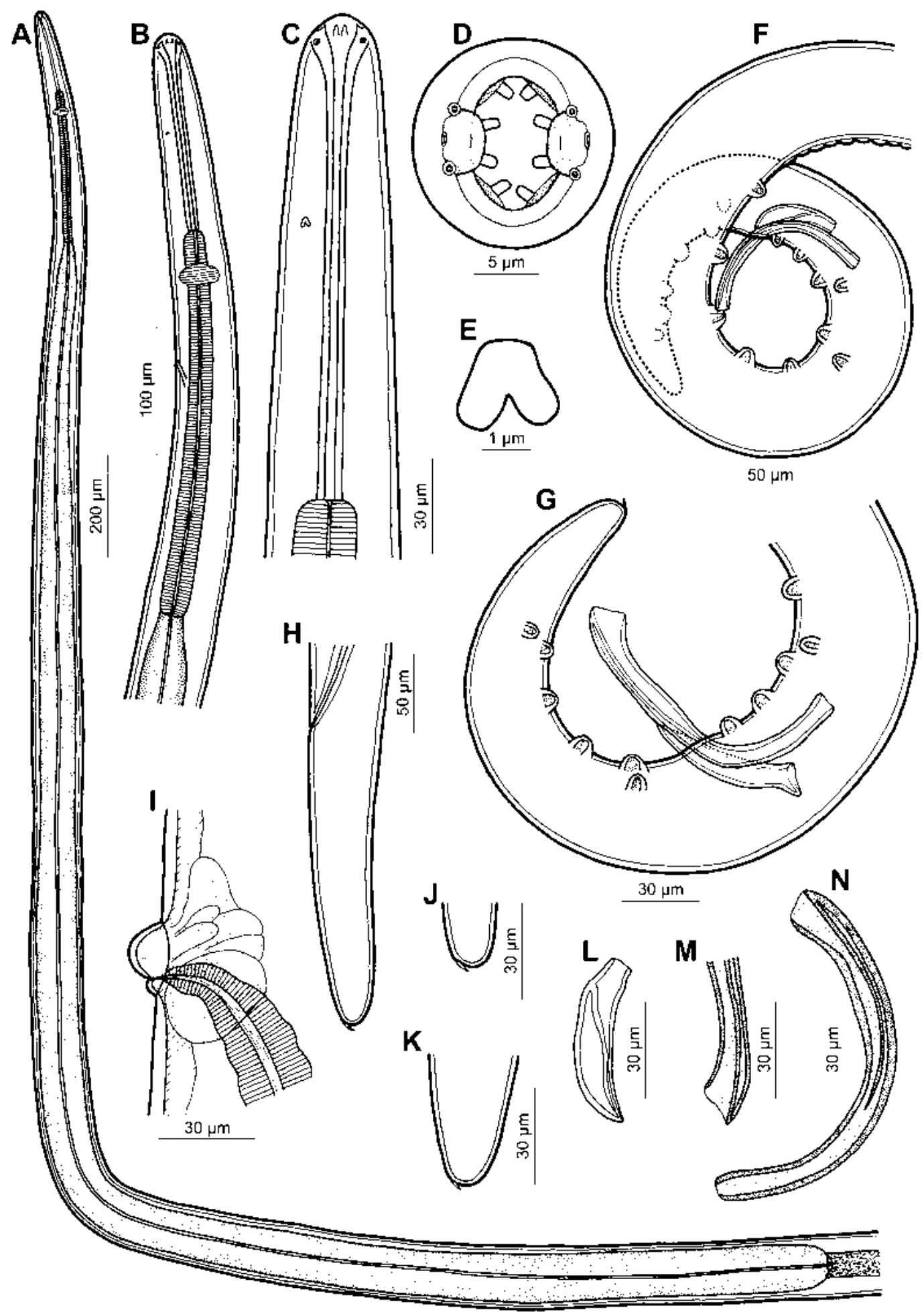

Fig. 3. Rhabdochona thaiensis sp. n. A - oesophageal part of body; B - anterior end of male, lateral view; C - anterior (vestibular) part of male body, lateral view; D - cephalic end, apical view; $\mathbf{E}$ - deirid; $\mathbf{F}$ - posterior end of male, lateral view; $\mathbf{G}$ - caudal end of male, lateral view; $\mathbf{H}$ - tail of female, lateral view; I - vulva, lateral view; J, K - tail tip of male and female, respectively, lateral views; $\mathbf{L}$ - right spicule; $\mathbf{M}$ - distal end of left spicule; $\mathbf{N}$ - left spicule. 

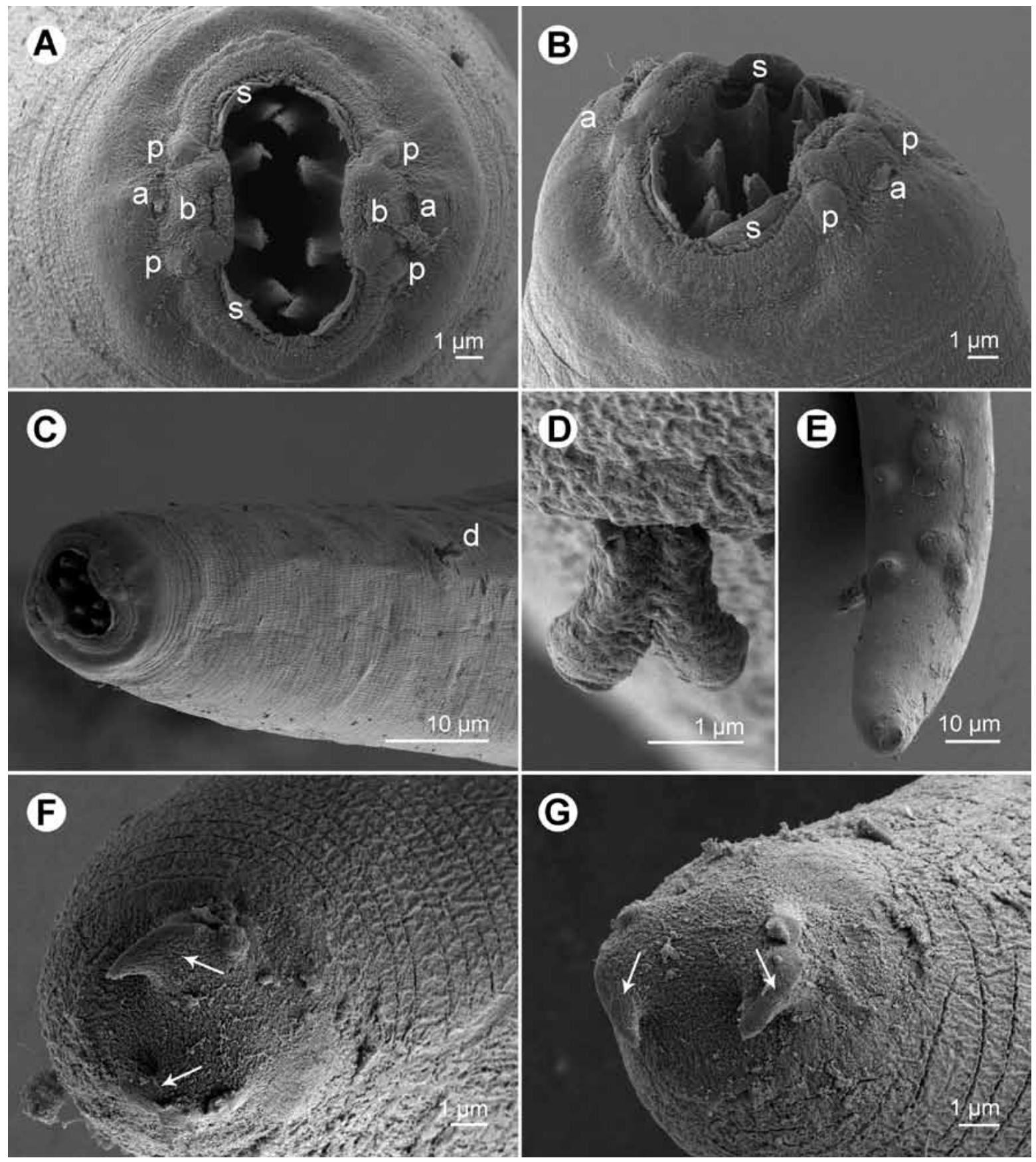

Fig. 4. Rhabdochona thaiensis sp. n., scanning electron micrographs of male. A, B - cephalic end, apical and dorsolateral views, respectively; $\mathbf{C}$ - anterior end of body, sublateral view; D - deirid; $\mathbf{E}$ - posterior part of tail, ventral view; $\mathbf{F}, \mathbf{G}$ - tip of tail at different positions, apical views (arrows indicate caudal projections). Abbreviations: $\mathrm{a}$ - amphid; $\mathrm{b}$ - pseudolabium; $\mathrm{d}$ - deirid; $\mathrm{p}$ - cephalic papilla; s - sublabium.

in China, R. sarana Karve et Naik, 1951 from Puntius sarana (Hamilton) in India, and $R$. wangi Moravec et Scholz, 1991 from Bagarius bagarius (Hamilton) and Zacco platypus (Temminck et Schlegel) in China (Karve and Naik 1951, Osmanov 1957, Campana-Rouget 1961, Majumdar and De 1971, Moravec 1972b, 1975, Wang and Guo 1983, Moravec and Scholz 1991, Wu et al. 1994).

Except for R. equispiculata, all other species possessing caudal projections are characterized by the presence of many $(>5)$ such projections, often arranged in a crownlike caudal appendage, but only in female, whereas the tails of conspecific males lack such structures (however, the male of $R$. sarana is unknown). On the contrary, $R$. equispiculata has caudal projections in both males and females, resembling thus $R$. thaiensis. However, whereas the former species has 3-4 spike-like caudal projections situated terminally on the tail tip, the latter possesses only 2 claw-shaped projections located on the ventral side 
of the tail tip. Both these species also markedly differ from each other in the lengths of spicules (213 and 147 in R. equispiculata vs. 135-141 and 60 in $R$. thaiensis) and their length ratio (1:1.2 vs. 1:2.3-2.4), presence vs. absence of basal prostomal teeth, and numbers and arrangement of preanal (15 vs. 5 pairs) and postanal (5 vs. 6 pairs) papillae. Nevertheless, both these probably related species occur in hosts belonging to the same family (Cyprinidae) in nearby regions (Laos and Thailand), but in different main river drainage systems (Mekong River basin vs. Chao Phraya River basin). As far as the authors know, unlike other species of Rhabdochona, R. equispiculata and $R$. thaiensis (and also the presently described $R$. pseudomysti) are characterized by distinctly elevated vulval lips, but less conspicuous than in R. pseudomysti.

According to Moravec (1975), species of Globochona belong to two morphological groups based on the character of fully developed eggs: A - species with smooth eggs; B - species with eggs provided with lateral swellings. However, the mature (containing a larva) eggs of $R$. thaiensis, as well as those of $R$. equispiculata, are unknown (only immature eggs were found in them); therefore, for the time being they cannot be assigned to any of the above-mentioned morphological groups.

In contrast to other species of Rhabdochona, in which pseudolabia are practically absent or slightly outlined (Moravec 1972a), those of $R$. thaiensis are distinct (Figs. $3 \mathrm{D}, 4 \mathrm{~A}, \mathrm{~B})$. This supports the opinions of some authors (e.g., Skryabin et al. 1967, Trofimenko 1967, Puylaert 1973, McVicar and Gibson 1975, Mejía-Madrid et al. 2007, Moravec 2007) that rhabdochonids show affinities with some members of Cystidicolidae (generally characterized by the presence of pseudolabia), recently also confirmed by molecular studies of Černotíková et al. (2011). It also confirms that species of Globochona are characterized by some primitive morphological features (in this case the presence of well-developed pseudolabia) indicating, along with their ancient groups of hosts, that they are probably closest to the initial type of Rhabdochona (see Moravec 2010).

\section{REFERENCES}

Aguilar-Aguilar R., Rosas-Valdez R., Pérez-Ponce de León G. 2010: Rhabdochona ictaluri sp. nov. (Nematoda, Rhabdochonidae) from ictalurid catfishes in Mexico. Acta Parasitol. 55: 276-280.

Boomker J., Petter A.J. 1993: Parasites of South African freshwater fish. III. Rhabdochona (Rhabdochona) versterae $\mathrm{n} . \mathrm{sp}$. (Nematoda: Rhabdochonidae) from the spot-tailed robber, Alestes imberi Peters 1852. Onderstepoort J. Vet. Res. 60: 23-27.

Campana-Rouget Y. 1961: Nématodes de poissons. Résultats scientifiques de l'exploration hydrobiologique des lacs Kivu, Édouard et Albert (1952-1954), 3: 1-61.

Caspeta-Mandujano J.M., Cabañas-Carranza G., Salgado-Maldonado G., Gosztonyi A.E., Cremonte F. 2005 :
A remarkable feature of $R$. thaiensis is the presence of four fairly large, elongate submedian inner structures in the mouth, resembling those in most representatives of Cystidicolidae, where these are usually designated as sublabia, following the terminology proposed by Margolis (1977). In some species of Rhabdochona, similar submedian structures, but much smaller and usually triangular in shape, were described as internal labial papillae, papilla-like structures or lateral plates (e.g., Boomker and Petter 1993, Caspeta-Mandujano et al. 2001, Cremonte et al. 2002). Although in most species of Rhabdochona these structures have not been described (they are clearly visible only by SEM), in our opinion, they are generally present in all representatives of this genus and are homologous with sublabia in cystidicolids. The character of these mouth structures in $R$. thaiensis also confirms affinities of this species with members of Cystidicolidae.

In Thailand, Kumchoo (2000) reported unidentified Rhabdochona sp. I from eight species of fish hosts, including Mystacoleucus marginatus, the type host of R. thaiensis. However, the morphology of Rhabdochona sp. I is very different from that of $R$. thaiensis; it is easily distinguished from the new species, e.g., by the number (14) of anterior prostomal teeth, absence of caudal projections, length of the left spicule (230-350) or structure of distal tips of both spicules. In contrast to $R$. thaiensis belonging to the subgenus Globochona, Rhabdochona sp. I is evidently a member of the nominotypical subgenus Rhabdochona.

Acknowledgments. We wish to express our thanks to the Office of the Higher Education Commission, Thailand for supporting this research by a grant fund under the program Strategic Scholarships for Frontier Research Network for the Ph.D. Program Thai Doctoral Degree, and to the Applied Parasitology Research Laboratory, Department of Biology, Faculty of Science, Chiang Mai University for providing necessary facilities. Thanks are also due to the staff of the Laboratory of Electron Microscopy, Institute of Parasitology, BC ASCR, in České Budějovice for their technical assistance, and to Blanka Škoríková of the same Institute for the help with illustrations. This study was partly supported by the research projects of the Institute of Parasitology, ASCR (Z60220518 and LC522).

Nematode parasites of the characid freshwater fish Brycon guatemalensis in the Usumacinta River, Chiapas, Mexico. Helminthologia 42: 41-44.

Caspeta-Mandujano J.M., Moravec F., Salgado-Maldonado G. 2001: Two new species of rhabdochonids (Nematoda: Rhabdochonidae) from freshwater fishes in Mexico, with a description of a new genus. J. Parasitol. 87: 139-143.

Cremonte F., Navone G.T., Gosztonyi A.E., Kuba L. 2002: Redescription of Rhabdochona (Rhabdochona) acuminata (Nematoda: Rhabdochonidae) from freshwater fishes from Patagonia (Argentina), the geographical implications. J. Parasitol. 88: 934-941. 
Černotíková E., Moravec F., Horák A. 2011: Phylogenetic relationships of some spirurine nematodes (Nematoda: Chromadorea: Rhabditida: Spirurina) parasitic in fishes inferred from SSU rRNA gene sequences. Folia Parasitol. 58: 135-148.

DJaliLov U.D. 1964: [Rhabdochonid materials (Rhabdochona Railliet, 1916) from fishes of the River Vakhsh and nearby lakes.] Izv. AN Tadj. SSR, Otd. Biol. Nauk, 1 (15): 109-117. (In Russian.)

Froese R., Pauly D. (Eds.) 2010: FishBase. World Wide Web electronic publication, www.fishbase.org, 10/2010.

Kakar A., Bilqees F.M., Kamran K., Mukhtar G.-S. 2010: Rhabdochona (Filochona) gubernaculus new species (Nematoda: Rhabdochonidae) from riverine fish Cyprinion watsoni (Day, 1872) in Balochistan, Pakistan. Pak. J. Zool. 42: 75-80.

Karve J.N., Naik G.G. 1951: Some parasitic nematodes of fishes - II. J. Univ. Bombay, New Ser., 19: 1-37.

Kumchoо K. 2000: Survey of Nematodes and SEM of Tegument in Freshwater Fishes from Maesa Stream, Doi Suthep-Pui National Park, Chiang Mai Province. PhD thesis, Faculty of Science, Chiang Mai University, 168 pp. (In Thai with English abstract.)

Majumdar G., De N.C. 1971: Rhabdochona barusi sp. nov. from the fish Barilius sp. with the key to the Indian species of this genus. Folia Parasitol. 18: 381-384.

Margolis L. 1977: Caballeronema gen. nov. for Metabronema wardlei Smedley, 1934 (Nematoda, Spiruroidea) from the marine fish Scorpaenichthys marmoratus from the Pacific coast of Canada. In: Excerta Parasitológica en Memoria del Doctor Eduardo Caballero y Caballero. Instituto de Biología, Universidad Nacional Autónoma de México, Publicaciones Especiales 4, Mexico City, pp. 447-454.

McVicar A.H., Gibson D.I. 1975: Pancreatonema torriensis gen. nov., sp. nov. (Nematoda: Rhabdochonidae) from the pancreatic duct of Raja naevus. Int. J. Parasitol. 5: 529-535.

Mejía-Madrid H.H., Choudhury A., Pérez-Ponce de León G. 2007: Phylogeny and biogeography of Rhabdochona Railliet, 1916 (Nematoda: Rhabdochonidae) species from the Americas. Syst. Parasitol. 67: 1-18.

Moravec F. 1972a: General characterization of the nematode genus Rhabdochona with a revision of the South American species. Acta Soc. Zool. Bohemoslov. 36: 29-46.

Moravec F. 1972b: A revision of African species of the nematode genus Rhabdochona Railliet, 1916. Acta Soc. Zool. Bohemoslov. 36: 196-208.

Moravec F. 1975: Reconstruction of the Nematode Genus Rhabdochona Railliet, 1916 with a Review of the Species Parasitic in Fishes of Europe and Asia. Studie ČSAV No. 8. Academia, Prague, $104 \mathrm{pp}$.

Moravec F. 1983: Rhabdochona puylaerti sp. n. (Nematoda: Rhabdochonidae) recorded from the African viper Causus rhombeatus (Lichtenstein). Folia Parasitol. 30: 313-317.

Moravec F. 2007: Some aspects of the taxonomy and biology of adult spirurine nematodes parasitic in fishes: a review. Folia Parasitol. 54: 239-257.

Moravec F. 2010: Some aspects of the taxonomy, biology, possible evolution and biogeography of nematodes of the spirurine genus Rhabdochona Railliet, 1916 (Rhabdochonidae, Thelazioidea). Acta Parasitol. 55: 144-160.

Moravec F., Amin A. 1978: Some helminth parasites, excluding Monogenea, from fishes of Afghanistan. Acta Sci. Nat. Acad. Sci. Bohemoslov. Brno 12: 1-45.
Moravec F., Arai H.P. 1971: The North and Central American species of Rhabdochona Railliet, 1916 (Nematoda: Rhabdochonidae) of fishes, including Rhabdochona canadensis sp. nov. J. Fish. Res. Board Can. 28: 1645-1662.

Moravec F., Řína M., Kuchta R. 2008: Two new nematode species, Paragendria papuanensis sp. n. (Seuratoidea) and Rhabdochona papuanensis sp. $\mathrm{n}$. (Thelazioidea), from freshwater fishes in Papua New Guinea. Folia Parasitol. 55: 127-135.

Moravec F., Scholz T. 1991: Observations on some nematodes parasitic in freshwater fishes in Laos. Folia Parasitol. 38: 163$178+$ Plts. I-VIII.

Moravec F., Scholz T., Ash A., Kar P.K. 2010: New data on the morphology and taxonomy of three species of Rhabdochona (Nematoda: Rhabdochonidae) parasitizing fishes in India. Folia Parasitol. 57: 295-306.

Moravec F., Sey O. 1988: Nematodes of freshwater fishes from North Vietnam. Part 2. Thelazioidea, Physalopteroidea and Gnathostomatoidea. Acta Soc. Zool. Bohemoslov. 52: 176-191.

Moravec F., Vivas-Rodríguez C., Scholz T., Vargas-Vázquez J., Mendoza-Franco E., González-Solís D. 1995: Nematodes parasitic in fishes of cenotes (= sinkholes) of the Peninsula of Yucatan, Mexico. Part 1. Adults. Folia Parasitol. 42: $115-129$.

Osmanov S.O. 1957: A new nematode from fishes of the AmuDarya. Dokl. Akad. Nauk Uzb. SSR, No. 1, pp. 63-65. (In Russian.)

Pearse A.S. 1933: Parasites of Siamese fishes and crustaceans. J. Siam. Soc. Nat. Hist. 9 (Suppl.): 179-181.

Purivirojkul W. 2009: Fish parasite diversity in the Mekong River in the north of Thailand. KKU Sci. J. 37 (Suppl.): 62-70.

Puylaert F.A. 1973: Rhabdochonidae parasites de poissons africains d'eau douce and discussion systématique de ce groupe. Rev. Zool. Bot. Afr. 87: 647-665.

Ramallo G. 2005: Observations on two Rhabdochona species (Nematoda: Rhabdochonidae) from freshwater fishes in Argentina, including description of Rhabdochona fabianae $\mathrm{n}$. $\mathrm{sp}$. J. Parasitol. 91: 415-419.

Saraiva A.M., Moravec F. 1998: Redescription of Rhabdochona anguillae (Nematoda: Rhabdochonidae), a parasite of eel, $\mathrm{An}$ guilla anguilla, in Europe. Folia Parasitol. 45: 233-238.

Sirikanchana P. 1982: Check Lists of Parasites of Fishes in Thailand. Kasetsart University Museum of Fisheries, Bangkok, $11 \mathrm{pp}$.

Skryabin K.I., Sobolev A.A., Ivashkin V.M. 1967: [Spirurata of Animals and Man and the Diseases Caused by Them.] Part 4. Thelazioidea, Essentials of Nematodology 16. Nauka, Moscow, 624 pp. (In Russian.)

TrofimenKo V.YA. 1967: Reconstruction of the system of the family Rhabdochonidae Skryabin, 1946 based on the analysis of its phylogeny. Sbornik Rabot po Gelmintologii Ryb i Ptits. Izd. AN SSSR, Moscow, pp. 77-95. (In Russian.)

WANg P. 1986: Notes on six new species of Rhabdochonidae from fishes in China (Nematoda: Spiruodea [sic]). Acta Zootaxonom. Sin. 11: 351-364. (In Chinese with English summary.)

WANG P., Guo Q. 1983: Studies on some species of helminths from freshwater fishes in Yunnan, China. Oceanol. Limnol. Sin. 14: 92-102. (In Chinese with English abstract.)

Wu G., YU Y., Wu H. 1994: Studies on two new species of Rhabdochona (parasitic nematodes) from Wuling Mountain Region. Acta Hydrobiol. Sin. 18: 280-286. (In Chinese with English summary.) 